\title{
THE FARM RISK MANAGEMENT OF BESUKI NA- OOGST TOBACCO IN TANJUNGREJO VILLAGE, JEMBER REGENCY
}

\author{
Anggi Lian Yustin Pratama, , Soetriono, Jani Januar \\ Agribusiness Department, University Of Jember, Indonesia \\ *corresponding author: anggilian90@gmail.com
}

\begin{abstract}
Tobacco is considered as one of the commercial plantation crops which has high expected farming profit. Jember Regency is one of the areas in East Java Province that is recognized as production center of tobacco. The major variety of tobacco which can be planted in Jember Regency is the Besuki Na-Oogst's Tobacco. Besuki Na-Oogst's Tobacco provides high profit when it is compared to the other commodities cultivated in the area of Tanjungrejo Village. The research goals are to analyze: (1) the farmer's attitude to the risk in farm management, (2) the income of Besuki Na-Oogst Tobacco's farmers and (3) the factors that influence the income of Besuki Na-Oogst's Tobacco farmer in Tanjungrejo Village. The sample method used is simple random sampling. The econometric modeling employed is multiple regression analysis. The results show that (1) among the farmers of Besuki Na-Oogst's Tobacco is neutral to the risk; (2) the income on 2015 was decreased because of the eruption of Raung Mountain. It influenced all farmers in Tanjungrejo Village. The eruption of Raung Mountain caused the decreasing quality of tobacco leaves as well; (3) the factors affected the income of tobacco farmer in Desa Tanjungrejo was selling price, the cost of seed, labor costs, land area, and dummy of risk lover.
\end{abstract}

Keywords: tobacco, risk, attitude, income

\section{INTRODUCTION}

Tobacco is considered as the commercial plantation crops which is capable to producing high enough profit to farmers. Besuki Na-Oogst's Tobacco is one of tobaccos that used for basic ingredients to make cigars which almost of its products are exported. Jember regency is one of the areas in East Java province that known as tobacco city because Jember becomes the center of tobacco producer. One of the villages that became the area of Besuki Na-Oogst Tobacco plantation in Jember was Tanjungrejo Village.

Tanjungrejo geographical's area supports this tobacco and becomes the mainstay commodity in Tanjungrejo Village. Furthermorem it is a commercial commodity that is able to provide huge benefits when compared with other commodities in the area of Tanjungrejo such as rice, corn, chili, and others. Tobacco Farmers has many uncertainty risks that will affected their farming operations. Many factors affected the tobacco farming, such as weather conditions; prices at the time of harvest could drop; hired labour may not be available at peak times; and many else. All of these changes are examples of the risks that farmers face in managing their farm as a business. All of these risks affect their farm profitability.

According to Soetriono (2006: 39), the existence of dependence of agricultural activity on nature resulted in the risk of agricultural production. In these circumstances, the adverse effects of nature greatly affect the total agricultural yields. For farmers, production failures or production risks that often occur will affect their attitudes in making farming decisions. The risk of tobacco farmers in the village of Tanjungrejo in managing Besuki Na-Oogst tobacco is quite large, because the cost of production is also very high, while the production and price of tobacco commodities are always uncertain. There are several factors that can influence Besuki Na-oogst tobacco farming in Tanjungrejo, among others, factors of production and risk factors. Risk factors are social factors that can not be measured by numbers. Every year the farmer has decided to choose planting tobacco cultivation or to cease his enterprise and planting other farming enterprises by 
paying attention to the constraints that arise when the commodities are cultivated.

The constraints faced by Besuki Na-Oogst's tobacco farmers in Tanjungrejo typically include constraints from natural factors (weather, climate, geography, and natural disasters), uncertain price fluctuations, complicated tobacco plant maintenance process, and high production costs. One of the natural factors occurred in 2015, namely the eruption of Mount Raung which greatly affected the farming Besuki Na-Oogst Tobacco in the Tanjungrejo. The yield of tobacco has decreased in quality so that the selling price dropped drastically. It made the tobacco farmers suffered huge losses.

Every risk and uncertainty of farming will affect the attitude of tobacco farmers in Tanjungrejo and its income, where this attitudes usually become the basic of farmers to take decisions in the next tobacco cultivation. They will decide what to plant in next season, how much to plant and when to plant. These decisions may appear simple to do, but for each decision there are many possible consequences.

\section{RESEARCH METHODS}

The research area used purposive method. The selected research area is Tanjungrejo Village in Wuluhan Sub-district, Jember District. The research method used descriptive method and analytic method. The sampling method used Simple Random Sampling. Determination of the number of samples determined using Slovin formula with tolerance level of $15 \%$ and obtained 35 people as samples of the study. Data collection method in this research used method of interview and observation.

The attitudes of Besuki Na-Oogst tobacco farmers against the risks in Tanjungrejo can be determined using the Bernoulli method or quadratic utility function analysis tool. According to Soekartawi in Soetriono (2017: 36), procedures to analyze the farmer's attitude has several steps that are all obtained from the interview process to determine the value of the pessimist to be optimistic.Each farmer was asked to indicate the certain income that he or she would need to be indifferent between receiving certain amount and a lottery with the highest possible profit and the lowest each with a probability of 50:50. The utility function is a function of the relationship between the utility index and the independent variable of the value of the rupiah currency. Thus from the data of $\mathrm{CE}$ value determination and utility value, utility function can be estimated as follows:

$$
U=b_{0}+b_{1} M+b_{2} M_{2}
$$

With meanings as below:

a. If $\mathrm{b}_{2}>0$, farmer is risk lover

b. If $b_{2}<0$, farmer is risk averse

c. If $\mathrm{b}_{2}=0$, farmer is risk neutral

In the second problem, to know the income of tobacco farmers can be known by using income analysis with the formula as belows:

$$
\begin{aligned}
\pi & =T R-T C \\
\pi & =(P \cdot Q)-T C \\
& =P \cdot Q-(T V C+T F C)
\end{aligned}
$$

where:

$\pi=$ income $(\mathrm{Rp})$

$\mathrm{P}=\operatorname{Price}(\mathrm{Rp})$

$\mathrm{Q}=$ Quantity $(\mathrm{Kw})$

$\mathrm{TR}=$ Total Revenue $(\mathrm{Rp})$

$\mathrm{TC}=$ Total Cost $(\mathrm{Rp})$

In the third problem, to know the factors affecting the tobacco farmersincome can be known by using multiple regression analysis with dummy variables. The formula as belows:

$$
\hat{y}=b_{0}+b_{1} x_{1}+b_{2} x_{2}+b 3 x 3+b 4 x 4+b 5 x 5+
$$$$
b 6 x 6+b 7 x 7+b 8 x 8+b 9 d 1+b 10 d 2
$$

where:

$\hat{\mathrm{y}}=$ income $(\mathrm{Rp})$

$\mathrm{b} 0=$ constanta

b1-b10 = coefficient of regression

$\mathrm{x} 1=$ variable of productioni $(\mathrm{Kw})$

$\mathrm{x} 2$ = variable of selling price $(\mathrm{Rp})$

$\mathrm{x} 3$ = variable of seed cost $(\mathrm{Rp})$

$\mathrm{x} 4=$ variable of fertilizer cost $(\mathrm{Rp})$

$\mathrm{x} 5$ = variable of drugs cost $(\mathrm{Rp})$

$\mathrm{x} 6$ = variable of labor cost $(\mathrm{Rp})$

$\mathrm{x} 7=$ variable of land area (ha)

$\mathrm{x} 8=$ variable of experience (year)

$\mathrm{d} 1$ = variable of dummy risk attitudes; $\mathrm{d} 1=0$ : risk lover; $d 1=1$ :the others attitudes (risk neutral and risk averse).

$\mathrm{d} 2$ = variable of dummy risk attitudes, $\mathrm{d} 2=0$ : risk averse; $d 2=1$ : the others attitudes (risk neutral and risk lover).

According to Hasan (2012: 264, 267 and 271) to test which the independent variables influence the dependent or which the dependent variable is caused by the variation of the dependent variable, it can be calculated using the coefficient of determination. The coefficient of multiple determination or R2 lies between 0 and $1(0 \leq \mathrm{R} 2 \leq$ 1). To knowing how multiple regression coefficients simultaneously or together influenced 
the income of Besuki Na-Oogst tobacco farmers in the this area, used F-test. And to knowing part of variables influenced the income, it used t-test.

\section{RESULTS AND DISCUSSION}

\section{Besuki Na-Oogst tobacco farmer's attitude} toward the risk

Assessment of farmer in facing the risk of Besuki $\mathrm{Na}-\mathrm{Oogst}$ Tobacco farming in this area can be seen by data of acceptance of Besuki Na-Oogst's Tobacco farmers. The preference value of each Besuki Na-Oogst tobacco farmers was measured through the admissions data which tested by quadratic regression. Based on the results of the utility function analysis, obtained a fairly good estimation model as shown by high coefficient of determination (R2) that was between 0.93 to 0.99 and F-count was significant at 95 percent confidence level. This means that 93 to 99 percent of utility value variations were caused by the effect of acceptance or it can be said that there was a very strong relationship between the value of utility and acceptance. Based on the results, Table 1 shows the variation of Besuki Na-Oogst tobacco farmer's attitude in Tanjungrejo.

Table 1. Distribution of Besuki Na-Oogst tobacco farmer towards the risk in tanjungrejo village

\begin{tabular}{llll}
\hline No & $\begin{array}{l}\text { Farmer } \\
\text { Attitude }\end{array}$ & $\begin{array}{l}\text { Samples } \\
\text { (people) }\end{array}$ & $\begin{array}{l}\text { Precentage } \\
(\%)\end{array}$ \\
\hline 1. & Risk Lover & 3 & 8.57 \\
2. & Risk Neutral & 22 & 62.86 \\
3. & Risk Averse & 10 & 28.57 \\
\hline & Total & 35 & 100 \\
\hline
\end{tabular}

Table 1 explains that farmers as risk taker are 3 people $(8.57 \%)$, while farmers as risk-neutral are 25 people $(62,86 \%)$, and farmers as risk-averse are 10 people $(28,57 \%)$. The results of the analysis shows that the first hypothesis was reject. It shows most farmers has negative and positive coefficient $\mathrm{b}_{2}$ not significant, and most farmers have risk neutral, as many as 25 people $(62.86 \%)$. Most farmers behave neutrally caused Besuki Na-Oogst tobacco farming in this area has become a tradition (culture) and has been implemented for a long time. This is also explained in Wardani's study (2015: 31 ), that the neutral attitude of most sample farmers to the risks due to tobacco farming in Klaten Regency is a hereditary effort that farmers are well aware of the risks to be faced, whether production risk or price risk. So the magnitude of the risks and benefits expected by the farmers has the function of utility with a constant slope.

In 2015, the condition of Besuki Na-Oogst Tobacco farming in Tanjungrejo was affected by the eruption of Mount Raung. As a result, volcanic ash particles attach to the tobacco leaf surface and affecting the quality of tobacco leaves. The eruption of Mount Raung is one of the natural disasters that included to unknown risks by tobacco farmers in the Tanjungrejo. Weather at that time was very good for the cultivation of Tobacco Besuki Na-Oogst so it can be estimated the selling price in the high season. But farmers can not predict the incidence of Mount Raung that erupted so yields at that time actually became the worst crops during the tobacco farming planting. They got a large loss.

Based on the status of the land area, most of tobacco farmers in Tanjungrejo Village as the land owner farmer, on average has a small area. If farmers want to increase their production, the $\mathrm{Na}$ Oogst Tobacco farmers in Tanjungrejo Village have to lease the land to expand the land to be used. The results of the analysis of the utility function when divided by the status of land area can be seen in Table 2.

Table 2. Farmer Risk Attitude by Status of Land Area

\begin{tabular}{lllll}
\hline \multirow{5}{*}{$\begin{array}{l}\text { Fand } \\
\text { Area }\end{array}$} & $\begin{array}{l}\text { Risk } \\
\text { Averse } \\
\left(\mathrm{b}_{2}<0\right) \\
(\text { People })\end{array}$ & $\begin{array}{l}\text { Risk } \\
\left(\mathrm{b}_{2}=0\right) \\
(\text { People })\end{array}$ & $\begin{array}{l}\text { Risk } \\
\text { Lover } \\
\left(\mathrm{b}_{2}>0\right)\end{array}$ & $\begin{array}{l}\text { To- } \\
\text { (People })\end{array}$ \\
\hline Narrow & 10.00 & 8.00 & 0.00 & 18 \\
Wide & 0.00 & 14.00 & 3.00 & 17 \\
\hline Total & 10.00 & 22.00 & 3.00 & 35 \\
$(\%)$ & 28.57 & 62.85 & 8.57 & 100 \\
\hline
\end{tabular}

The land area used by farmers of respondents between narrow and wide area is almost balanced, which is 18 people with narrow land and 17 people wide. The profits of the Besuki Na-Oogst Tobacco crops are always better than other crops. It made some farmers expand their land by leasing system per year. It is also mentioned by Suratiyah (2015: 21) that the increase a land farm may be cultivated, the production and income per unit area will be higher.

The result of the tobacco farmer preference analysis with quadratic function (utility) in Table 2 shows that after statistical tests at 95 percent level, most farmers have negative b2 coefficient as well as positive but not significant. This value indicates 
that the farmer's behavior is risk neutral. Farmers who behave neutral amounted to 22 people $(62.85 \%)$ consisting of 8 peasants with narrow land and 14 farmers tobacco with a large area. Some risk neutral farmers are recognizing the uncertainties and risks of the Besuki Na-Oogst Tobacco farmers may encounter such as uncertain weather, yields produced, and selling prices. Tobacco farmers assumed that every farm would have a profit and loss, but Besuki Na-Oogst Tobacco farming has been considered to often give good results when compared with other farms. Tobacco farmers who behave risk neutral usually already have the next tobacco planting plan taking into account the weather conditions that will be encountered during the cultivation of Tobacco Besuki Na-Oogst. The planning can be the time of planting, regulation of fertilizer and pesticide, and the right time to harvest.

Farmers with risk lover had positive coefficient $b_{2}$ with significance less than 0.05 only amounted to 3 people $(8.57 \%)$ with ownership of lease land of more than 0.5 hectar. While the few $(28.57 \%)$ including risk averse with negative coefficient $b_{2}$ as much as 10 people which on average have a narrow land. Farmers who risk lover understand the opportunity of Besuki NaOogst Tobacco farm to be obtained. The farmers' desire to obtain a high profit of farming makes 3 farmers dare to spend a considerable production cost with a large area of land. The ability of technological mastery, such as the making of appropriate seeds, good planting time arrangement, and proper maintenance, as well as experience in support 3 brave tobacco farmers in making the right decision in every implementation of Besuki Naoogst Tobacco farm in the Village Tanjungrejo.

Risk averse farmers amounted to 10 people, known to 8 people are farmers owners and 2 farmers rent. Owner farmers usually have an area that is not too broad. The owner farmer in the village of Tanjungrejo has a tendency to behave neutrally to risk averse. According to Fauziyah et al. (2010: 117), the narrowness of land owned by farmers, the more fearful the farmers were against the risks. As a result, the inputs allocated in the farms were less and more inefficiently technically and allocatively, it implied the productivity and profit gained were small. Fears of smallholder farmers in Tanjungrejo caused they got risk averse. Thus some tobacco farmers either would not prefer to take a chance at the possible profit though it may have a probability of happening, than taking a safer position with a lesser possibility of incurring a large loss; or would prefer to use the income just for their consumption as farmers. Farmers who behave thus indicate that some Besuki Na-Oogst tobacco farmers in Tanjungrejo Village are still subsistent and semi-commercial.

\section{Income of Tobacco Farmers Besuki Na-Oogst in Tanjungrejo Village}

The income of Besuki Na-Oogst Tobacco farmers is known through income analysis. Total revenue of Tobacco Besuki Na-Oogst is obtained from the multiplication of tobacco products with Besuki NaOogst tobacco prices in dry tobacco state. The acceptance value of the Besuki Na-Oogst tobacco commodity in Tanjungrejo Village is often considered large compared to other farming products such as rice, maize, cabbage and chili.

The average cost incurred for Besuki NaOogst Tobacco farming is quite large, amounting to Rp 19,267,727.00 per MT / Ha. The average variable costs incurred by farmers in 2015 amounted to $\operatorname{Rp~12,305,224.00~per~hectare,~while~}$ the average fixed cost of $\mathrm{Rp} 6,962,503$. The amount of farming costs incurred due to tobacco is one of the leading commodities in the process of farming requires a variety of intensive care.

Based on research by Masruroh (2015: 49), tobacco farming is a business that had a greater advantage compared to other crops such as rice and vegetables. Farmers much interest to run this business by reason of the farming business were more contributed against household income of farmers to meet the needs and maintain the sustainability of their lives compared others crops such as rice and vegetables. These reasons are also valid for the tobacco farmers in this village since the result of the sale of tobacco been able to meet the needs of farmers although only grown seasonal.

However, in 2015, natural disasters had been occured, namely the eruption of Mount Raung which was located in the north of Jember regency. It caused Jember and surrounding areas got rain of volcanic ash for one to two months duration to the southern region of Jember Regency which is no other region of tobacco planting centers Besuki NaOogst. These conditions affected the existing farming activities in the village of Tanjungrejo especially Besuki Na-Oogst Tobacco farming. Quality of Besuki Na-Oogst Tobacco leaf became very bad because of the volcanic ash particles attached to the tobacco leaf. 
Table 3. Average of tobacco farmer's income

\begin{tabular}{llll}
\hline No & Items & Unit & Value \\
\hline 1. & Production & $\mathrm{Kw} / \mathrm{Ha}$ & 5.9 \\
2. & Price & $\mathrm{Rp} / \mathrm{Quintal}$ & 290,000 \\
3. & Revenue & $\mathrm{Rp} / \mathrm{Ha} /$ season & $2,473,754$ \\
4. & Total Costs & $\mathrm{Rp} / \mathrm{Ha} /$ season & $19,267,727$ \\
6. & Income & $\mathrm{Rp} / \mathrm{Ha} /$ season & $-16,793,973$ \\
\hline
\end{tabular}

Based on Table 3, it can be explained that the average of Besuki Na-Oogst tobacco products in dry conditions is obtained as much as 5.9 quintals per hectare with an average price of $\mathrm{Rp} 290.000,00$ per quintal. The fall in prices in the 2015 season is a sharp decline in prices when compared with previous years. Usually Besuki Na-Oogst tobacco farmers are able to sell dried tobacco crops with an average price of $\mathrm{Rp} 4,000,000.00$ to $\mathrm{Rp}$ $8,000,000.00$ per quintal. The average of total revenue only reached $\mathrm{Rp} 2,473,754.00$ per hectare. Whereas the average cost of Besuki Na-Oogst tobacco farming production is very high up to Rp 19,267,727.00 per hectare. These conditions make all Besuki Na-Oogst tobacco farmers in the Tanjungrejo suffered enormous losses. The average income received by tobacco farmers suffered losses of up to Rp 16,793,973.00.

Table 4. Distribution of income based on farmer's attitude toward the risk

\begin{tabular}{lccc}
\hline Attitude & Quantity & $\begin{array}{c}\text { Total } \\
\text { Income (Rp) }\end{array}$ & $\begin{array}{c}\text { Average } \\
\text { Income (Rp) }\end{array}$ \\
\hline $\begin{array}{l}\text { Risk lover } \\
\text { Risk }\end{array}$ & 3 & $-51,635,406$ & $-17,211,802$ \\
$\begin{array}{l}\text { Neutral } \\
\text { Risk }\end{array}$ & 22 & $-265,330,654$ & $-12,060,484$ \\
Averse & 10 & $-66,989,139$ & $-6,698,914$ \\
\hline TOTAL & 35 & $-383,955,199$ & $-35,971,200$ \\
\hline
\end{tabular}

Farming management of tobacco Besuki NaOogst suffered huge losses in 2015. Table 4 explains that farmers' risk lover income got an

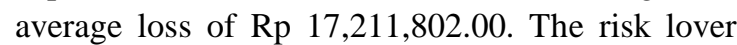
tobacco farmers were the greatest losses when compared to risk neutral farmers and risk averse. Risk neutral farmer got loss as much Rp $12,060,484.00$, it was still greater than that of risk averse farmers who got average losses of up to Rp $6,698,914.00$.

The decline in tobacco selling price is caused by the quality of tobacco leaves grown or harvested at the time of the volcanic ash becomes very bad. The volcanic ash rain caused the tobacco leaf surface to be covered by volcanic ash. The quality of leaves harvested in the 2015 season that contained volcanic ash affected the aroma, color, and even taste in the manufacture of cigars in large companies.

Differences in the income of farmers tobacco who be risk lover, neutral, and risk averse also caused by the production cost issued far greater while revenues obtained very small. Factors land area usually become one of the factors that affect the production factors issued . Fauziah et all. (2010: 120 ) also indicated that the risk of preference on farmers that have broad different land having the impact of different input on allocations used. Farmers who avoid the risk using input more little if compared with the farmers who neutral and risk lover, so that the efficiency of tobacco on farmers against risk neutral better than the farmers who always avoid the risk. The same thing also occurred in productivity and profits received by each farmer. Tobacco farmers who have large areas get bigger losses than tobacco farmers with narrow areas, because the production costs incurred by farmers with a large area is much larger.

Tabel 5. The Besuki Na-Oogst tobacco farmer's income based on land area

\begin{tabular}{lrrr}
\hline $\begin{array}{l}\text { Land } \\
\text { Area } \\
(\mathrm{Ha})\end{array}$ & Quantity & $\begin{array}{l}\text { Average of } \\
\text { Total Cost } \\
\text { (Rp/MT) }\end{array}$ & $\begin{array}{l}\text { Average } \\
\text { Income } \\
\text { (Rp/MT) }\end{array}$ \\
\hline $\begin{array}{l}\text { Narrow } \\
(<0,5)\end{array}$ & 18 & $8,262,123$ & -7.122 .123 \\
$\begin{array}{l}\text { Large } \\
(>0,5)\end{array}$ & 17 & 17.444 .823 & -15.055 .117 \\
\hline Total & 35 & 25.706 .946 & -22.167 .239 \\
\hline
\end{tabular}

Based on Table 5, the total amount of sample farmers with a narrow land were 18 people and sample farmers with large area 17 people were. Farming average costs incurred by tobacco farmers having broad narrow land much smaller $\mathrm{Rp}$ 8.262.123,00, compared to farmers who has extensive land, the cost to Rp 17.444.823,00 per a growing season. Besuki Na-oogst Tobacco farmers that have narrow land got losses until $\mathrm{Rp}$ 7.122.123, and farmers with large land losses until Rp 15.055.117,00. Tobacco farmers in Tanjungrejo Village have taken action to reduce the volcanic ash attached to the leaf surface such as spraying water into tobacco plants before harvesting, cleaning the leaves during drying process, until special treatment after dry tobacco. But it still can not make the dust that stick really lost so that the selling price did not increase. This makes the tobacco farmers in the village of Tanjungrejo suffered huge losses and the largest during their planting of tobacco. 


\section{Factors Affecting Income of Tobacco Farmers Besuki Na-Oogst in Tanjungrejo Village}

Factors affecting the income of Besuki Na-Oogst tobacco farmers in the village of Tanjungrejo can be known by performing multiple linear regression analysis on income. Regression analysis was estimated to investigate the socioeconomic variables on farmers' income in the study area . The value of $F$ test was 36,928 with significance $0.000 \mathrm{a}$ or no greater than 0,05 which means regression model can be used to predicted the income of Besuki Na-Oogst tobacco farmer in Tanjungrejo Village. The significance value of $0.000 \mathrm{a}<0.005$ can mean that simultaneously the independent variables (production, selling price, seed costs, fertilizer costs, drug costs, labor costs, land area, experience, and dummy risk lover and dummy risk averse) simultaneously affected income. Result of the analysis showed the value of Adjusted $\mathrm{R}^{2}$ on model was 0.914 which means 91.4\% of Besuki Na-Oogst tobacco farmer income in Tanjungrejo Village was influenced by independent variables in model, while $8.6 \%$ farmer's income influenced by other variables outside the regression equation model.

The next test is a partial test (t-Test) which is useful to know the magnitude of partial influence of each independent variable to dependent variable that is income of Besuki Na-Oogst tobacco farmer in Tanjungrejo Village. The result of multiple linear regression analysis can be written into equation model as follows:

$$
\begin{aligned}
\hat{y}= & -3132,630+68,179 \times 1+13,461 \times 2+2,053 \times 3 \\
& -2,377 \times 4-2,531 \times 5-1,311 \times 6-4971,60 \times 7 \\
& +25,027 \times 8-2776,576 \mathrm{~d} 1+245,987 \mathrm{~d} 2
\end{aligned}
$$

The equation shows the constant value of 3132,630 means if the factor of free variable value is 0 , then the income of tobacco farmers suffered a loss of $\operatorname{Rp~3,132,630.00.~The~influence~of~each~}$ independent variable to the dependent variable of tobacco farmer income in Tanjungrejo Village can be explained as follows.

\section{Production $\left(\mathrm{x}_{1}\right)$}

The production factor has positive regression coefficient which means there is positive influence between independent variable of production and income. The value of regression coefficient obtained is 68,179 means that every additional production of 1 quintal will increase income of $\mathrm{Rp}$ $68.179,00$ with assumption other variable constant. The result of statistical test shows that the factor of production has no significant effect on income in
Tanjungrejo Village with $95 \%$ confidence level (significance 0,642>0,05). Based on the results of the analysis, the hypothesis is rejected. Production has no significant effect on tobacco farmer income in Tanjungrejo Village.

Production of Besuki Na-oogst tobacco in 2015 had no significant effect on income due to Besuki Na-Oogst tobacco production when it had very low quality. Bad tobacco quality is caused by the impact of volcanic ash from Mount Raung that erupted at the time. Volcanic ash particles rained almost every tobacco plant in Jember district, one of them in Tanjungrejo Village. Volcanic ash particles derived from the eruption of Mount Raung attached to the tobacco leaf surface, and difficult to clean because of the stickiness on the surface of the tobacco leaf. Toasted Besuki Na-Oogst tobacco leaves are very bad. It is known from the condition of the leaves are less elastic, leaf color to brown with round spots on the surface, and feels rough when held due to the volcanic ashes are hard to remove. In addition, the presence of volcanic ash that is still attached to tougher leaf Besuki NaOogst is considered will affect the flavor of the cigar to be made. The production of such products when sold will enter the quality of the filler at a very low price.

Some farmers are aware of it while tobacco is still a lot of which has not been harvested decided to stop the harvest, because it is considered that the harvested product will still be unable to pay the labor used. Some of the tobacco that has been harvested and included in the drying process is eventually sold by farmers at a price that is already known, which ranges from $\mathrm{Rp} 150.000,00$ to $\mathrm{Rp}$ $350,000.00$ per quintal. This condition makes tobacco farmers Besuki Na-Oogst suffered huge losses.

\section{Selling Price $\left(\mathrm{x}_{2}\right)$}

The selling price factor has a positive regression coefficient that means there is a positive influence between independent variables selling price with income. The coefficient value obtained is 13,461 , it means that every increase of selling price by 1 rupiah can increase income equal to $\mathrm{Rp}$ $13,461,00$ with assumption of other independent variable constant. The result of statistical test shows that the selling price factor significantly influence to Besuki Na-Oogst tobacco farmer income in Tanjungrejo with $95 \%$ confidence level (significance $0,020<0,05$ ). Based on the results of the analysis, the hypothesis of the selling price factors that have a real effect on income can be accepted. 
The tobacco sale price in 2015 is a very low price of tobacco ever received by Besuki Na-Oogst tobacco farmers. Such conditions are caused by the impact of the eruption of Mount Raung. Quality of Besuki Na-Oogst tobacco leaf is included in the quality with the overall filler grade so the selling price offered becomes very low. The selling price offered due to the eruption of Mount Raung ranged from $\mathrm{Rp} 150.000,00$ to $\mathrm{Rp} 350.000,00$ per kwintal or the average selling price offered to tobacco farmersbesuki Na-Oogst in Tanjungrejo Village only reached $\mathrm{Rp} 290.000,00$ per kwintal. In fact, under normal conditions the price of tobacco for the quality of dekblad up to Rp 8.000.000,00 per quintal can even more, while the quality of the filler still get the price range of $\mathrm{Rp} 1,000,000.00$ per quintal. The very low selling price of the 2015 planting season is very influential on farmers' income. Farmer income in 2015 is very small, even farmers suffered huge losses when compared to crops in previous years.

\section{Seed Cost}

Seed cost factor has positive regression coefficient which means there is positive influence between independent variable cost of seed and income. The value of coefficient obtained is 2.053, it means that every increase of seed cost of 1 rupiah hence can increase income equal to $\mathrm{Rp} 2,053,00$ with assumption other independent variable constant. The result of statistical test shows that the cost factor of seedlings significantly affect the income of Besuki Na-Oogst tobacco farmers in Tanjungrejo Village with $95 \%$ confidence level (significance $0.014<0.05$ ). The positive relationship between seed costs and farmer income can be seen in Figure 1.

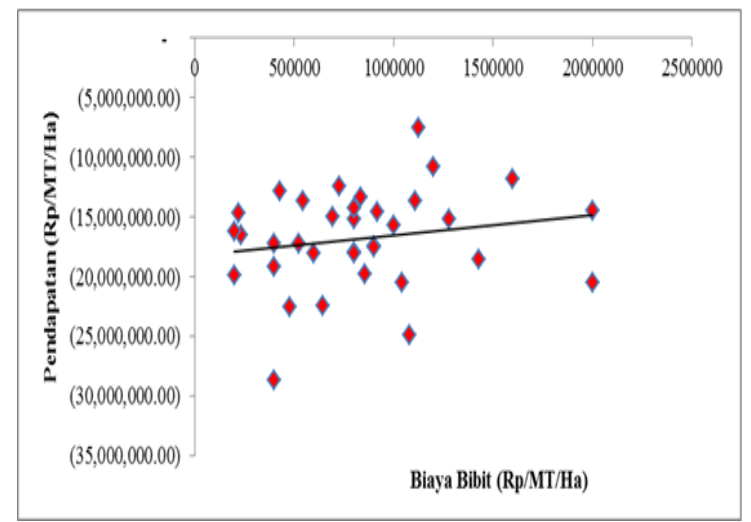

Figure 1. The Average Income of Tobacco Farmers Based on Kind of Seeds

Seeds used by farmers are usually obtained from tobacco farmers around who are able to produce their own. Besuki Na-Oogst tobacco farmers with each other still have a brotherly relationship so that the seeds sold to Besuki NaOogst tobacco farmers around can still be reached and have a very cheap price when compared to buying seeds from other tobacco companies. Figure 1 explains the cost of seeds issued by tobacco farmer respondents in the village of Tanjungrejo with income received. The line in Figure 1 shows the positive direction, which means the addition of seed costs can increase the income of the farmers. In the tobacco planting season of 2015, Tobacco farmers Besuki Na-Oogst suffered high losses due to the impact of Mount Raung erupted, which average loss of up to $\mathrm{Rp} 15,966,735.29$ per hectare for farmers who use polybag seeds, while tobacco farmers who use removal seedlings experience higher losses, the average is around $\mathrm{Rp}$ $17,200,207,51$.

The losses of farmers who use removal seeds are higher when compared with farmers who use polybag seeds, meaning that farmers who spend a little higher for seeds (farmers using polybag seeds) are able to earn higher income compared with farmers who use removal seedlings. This is also revealed by Suratiyah (2015: 65) who argues that in general high-priced production factors will give high yields and on the contrary the low price will give a low result too. Substitution laws should be terminated in the event of a technical loss due to substitution of goods that eliminates the benefits obtained because of lower prices. Although the price of polybag seeds is slightly more expensive than seedlings unplug but still able to give higher profits compared with seedlings unplug.

\section{Fertilizer Costs (x4)}

The cost factor of fertilizer has negative regression coefficient which means there is a negative effect between independent variable of fertilizer cost and income. The value of coefficient obtained for - 2.377 means that any increase of fertilizer cost of 1 rupiah then it can decrease income of $\mathrm{Rp} 2.377,00$ with assumption other independent variable constant. The result of statistical test shows that the fertilizer cost factor has no significant effect on the income of Besuki Na-Oogst tobacco farmers in Tanjungrejo Village with 95\% confidence level (significance 0,107> $0,05)$. The cost of fertilizer that has no significant effect on income due to the fertilizer issued for Besuki Na-Oogst tobacco farming in Tanjungrejo Village is quite large and large. Tobacco farmers in the village of Tanjungrejo use a lot of inorganic fertilizer in the farm. This condition is the same as 
that expressed in Soetriono et al. (2014: 46-47) which states that the farmers of Tobacco Besuki Na-Oogst in Jember area use excessive fertilizer and not according to the standard of fertilization according to the Jember District Plantation Office. When compared to the dose of fertilizer use by tobacco farmers with the recommendation of Dinas Perkebunan very different.

Farmers spend more on buying inorganic fertilizers such as Urea, KS, KNO3, ZA, and SP-36 expecting tobacco yields to be expected. The five fertilizers are fertilizers containing many of the nitrogen elements needed by Besuki Na-Oogst tobacco plants. This is supported by Inayatin research (2011: 95) which says that nitrogen compounds present in Urea fertilizer can increase the quantity of tobacco products and form protein and nicotine compounds that can affect the quality of tobacco. Besuki Na-Oogst tobacco farmers in Tanjungrejo Village paid an average fertilizer cost

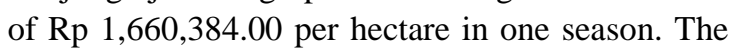
cost of fertilizer is still relatively cheap because some of the fertilizers used such as Urea fertilizer still get subsidy from the government that is managed by each farmer group. So the expenditure of fertilizer cost of tobacco farmers in Tanjugrejo Village helped by the subsidy.

\section{The Cost of Agricultural Drugs (x5)}

The drug cost factor has negative regression coefficient which means there is negative effect between independent variable of drug cost with Besuki Na-Oogst tobacco farmer income. Coefficient value obtained for -2.531 means that any increase in drug costs by 1 rupiah then it can decrease income by $\mathrm{Rp} 2.531,00$ assuming other independent variables are constant. The result of statistical test showed that the cost factor of medicines had no significant effect on the income of Besuki Na-Oogst tobacco farmers in Tanjungrejo Village with 95\% confidence level (significance $0,163>0,05$ ).

The results of Inayatin's research (2011: 90) explained that the cost of pesticides has no significant effect on the income of Besuki NaOogst tobacco farmers in Jember District because the percentage of pesticide cost is relatively small for Na-oogst tobacco when compared with other farming cost components. This also happened to Besuki Na-Oogst tobacco farmers, especially those living in Tanjungrejo Village. Besuki Na-Oogst tobacco farmers in this area will not use pesticides / tobacco drugs if there is no serious threat of pests and diseases. The average cost of medicines issued by Besuki Na-Oogst tobacco farmers in Tanjungrejo ranges from $\mathrm{Rp} 803,393.00$ or only about $3.77 \%$ of the total production cost. The percentage of drug cost is the smallest cost percentage of its value in Besuki Na-Oogst tobacco farming in Tanjungrejo Village, so the cost of medicine in Tanjungrejo Village has no significant effect on income.

\section{Labor Cost (x6)}

Labor cost factor has negative regression coefficient which means there is negative influence between independent variable of labor cost and income. The coefficient value obtained is -1.311 , it means that every increase of labor cost of 1 rupiah hence can decrease income equal to Rp 1.311,00, assuming other independent variable constant. The result of statistical test shows that labor cost factor significantly influence to Besuki Na-Oogst tobacco farmer income in Tanjungrejo Village with $95 \%$ confidence level (significance $0,000<0,05$ ).

Percentage of labor cost is the biggest percentage of cost in total production cost, that is reach $36,50 \%$. The condition is also explained by Suratiyah (2015: 30) who said that the type of commodity will determine the amount of labor. In general, seasonal crops require more labor than annual crops. Distribution of labor per year is uneven because it depends on the season. Tobacco belongs to a group of seasonal crops. In addition, the complex process of tobacco maintenance makes the required labor on Besuki Na-Oogst tobacco farm more in comparison with other seasonal crops.

\section{Land Area (x7)}

The land area has negative regression coefficient which means there is negative influence between independent variable of land area with the income of Besuki Na-Oogst Tobacco farmer in Tanjungrejo Village. The value of regression coefficient obtained is $-4971,60$, it means that every addition of land area of $1 \mathrm{Ha}$ will decrease the income of Besuki Na-Oogst tobacco farmer equal to $\mathrm{Rp} 4.971 .600,00$ with assumption other variable remain. The result of statistical test shows that land area factor significantly influence to Besuki Na-Oogst tobacco farmer income with $95 \%$ (significance $0,035<0,05$ ). So, the land area has a significant effect on farmer's income, hence the hypothesis can be accepted.

As the area of Besuki Na-Oogst tobacco farming increases, the greater the production factor will be required, which means the production cost will be greater than that of the farmers who use the land with a narrow area. However, if risk factors 
affect farming activities of tobacco farmers such as volcanic ash rain in the 2015 planting season will cause farmers' income to experience greater losses as well when compared with small farmers. This condition can be seen from the income of Besuki Na-Oogst tobacco farmers in the Village Tanjungrejo planting season 2015 when the eruption of Mount Raung. Farmers who have narrow land suffered a smaller loss of $\mathrm{Rp}$ $7,122,123.00$ while tobacco farmers who have a large area of income had a loss of up to $\mathrm{Rp}$ 15,055,117.00.

In the condition of Besuki Na-Oogst Tobacco farming that experienced uncertainty as affected by the eruption of Mount Raung actually make farmers who have large area of land suffered greater losses due to large production costs used, which ranges from $\mathrm{Rp} 17.444 .823,00$, while the received revenue is very small because dry tobacco is only able to sell at an average price of $\mathrm{Rp}$ $290.000,00$ per quintal.

\section{Experience (x8)}

Experience factor has positive regression coefficient which means there is positive influence between independent variables of experience with income of Tobacco farmer Besuki Na-Oogst in Tanjungrejo Village. The regression coefficient value obtained is 25,027 , which means that every year experience increase will be able to increase income of Besuki Na-Oogst Tobacco farmer equal to Rp 25,027 assuming other variable constant. The result of statistical test shows that the experience factor has no significant effect on the income of Tobacco farmer Besuki Na-Oogst with $95 \%$ confidence level (significance 0,731>0,05). All farmers with both longer experience and shorter experience in tobacco cultivation suffer substantial losses by 2015. This is because all the tobacco Besuki Na-oogst tobacco planted has a very poor quality due to volcanic ash particles attached on the tobacco leaf surface. Farmers can not bargain for higher prices because of it. Experienced farmers long enough and fewer experienced farmers suffered losses. In fact Suratiyah (2015: 27) states that a person's skills determine its performance. Someone who is more capable of course his performance is higher when compared with someone who is less skilled.

\section{Dummy Risk Taker Attitude (x9)}

The dummy factor of risk taker attituder has negative regression coefficient which means there is a negative effect between the risky farmer's behavior variable with the income of Besuki Na-
Oogst tobacco farmer in Tanjungrejo Village. Regression coefficient value obtained is equal to 2776,576 which shows that the income of brave farmers at risk of losses so that the income is lower by $\mathrm{Rp} 2.776 .576,00$ when compared with the earnings of farmers who behave others (neutral and not dare to risk) with the assumption variable another constant. The result of statistical test shows that brave risk factor has a significant effect on toukiBesuki Na-Oogst farmer's income in Tanjungrejo Village with $95 \%$ confidence level (significance $0,022<0,05$ ).

Besuki Na-Oogst tobacco farmers are brave at risk of having an average land area and production facilities are large enough when compared with other farmers (neutral and not dare to risk). Farmers are brave at risk of a $50 \%$ chance of making a profit and losing money. The desire to earn a high income makes brave farmers at risk of costing more for Besuki Na-Oogst tobacco production in the village of Tanjungrejo. This will certainly increase the income of farmers who behave boldly risky if the selling price and high production. But conditions in the tobacco season in 2015 natural disasters erupted Mount Raung unexpected. The village of Tanjungrejo became one of the villages that received the impact of volcanic ash rain, affecting Besuki Na-Oogst tobacco farming especially on the quality of tobacco leaves produced. As a result, the selling price of the season has dropped considerably compared to previous years, reaching an average selling price of $\operatorname{Rp} 290.000,00$ per quintal.

Besuki Na-Oogst's tobacco farmers who have a risk lover have a significant effect on earnings,because risk lover farmers spend more on production processes so that when uncertainty causes losses. Farmers' income is much lower risk compared to other behavioral farmers (neutral and not at risk). In accordance with the study that independent variables dummy bold behavior have a significant effect on income and have a negative regression coefficient value which can be concluded that independent variables dummy behavior bold at risk Besuki Na-Oogst tobacco farmers can reduce income.

\section{Dummy risk averseattitude(x10)}

Dummy factor of risk averseattitude has positive regression coefficient which means there is positive influence between behavioral variable not dare risk with income of Besuki Na-Oogst tobacco farmer in Tanjungrejo Village. The value of regression coefficient obtained is 245,987 
indicating that farmer income not dare risk higher Rp 245,987,00 when compared with earnings of other behavioral farmer (neutral and dare to risk) with assumption other variable constant. The result of statistical test shows that behavioral factor does not have the risk to have no significant effect on the income of Besuki Na-Oogst tobacco farmers with $95 \%$ confidence level (significance 0,726>0,05). Dummy results do not dare risk having no real effect on income, so the hypothesis is rejected.

Besuki Na-Oogst tobacco farmers who behave unkindly at risk always consider carefully made decisions. Farmers who do not dare to risk are farmers who tend to have a small area of land so do not dare in allocating the area of land owned by factors of production to increase production. However, when a natural disaster, for example Mount Raung eruption that causes volcanic ash rain in 2015, the income of farmers who do not dare risk less loss when compared with other farmers who behave neutral and dare to risk. This is because in that season the price decline is very low ie from the price range $\mathrm{Rp} 4,000,000.00$ to $\mathrm{Rp}$ $8.000 .000,00$ per quintal only becomes $\mathrm{Rp}$ $250.000,00$ to $\mathrm{Rp} 350.000,00$ just per quintal causing all farmers tobacco in the village of Tanjungrejo suffered huge losses.

\section{CONCLUSION}

Besuki Na-Oogst Tobacco farmers in Tanjungrejo village who are categorized as neutral to risk as much as 25 people $(71.43 \%)$, risk averse as many as 10 people $(28.57 \%)$ and risk lover as many as 3 people $(8.57 \%)$. Most of farmers are risk neutral because the tobacco farming has became a tradition (culture) and has been implemented for a long time. The farmers' income in 2015 is not beneficial due to volcanic ash caused by the erupting volcano so that all tobacco farmers in Tanjungrejo Village suffered losses up to $\mathrm{Rp}$ 16,793,973.00 per planting season / Ha. Factors that significantly affect tobacco farming income are selling price $\left(\mathrm{x}_{2}\right)$, seed cost $\left(\mathrm{x}_{3}\right)$, labor cost $\left(\mathrm{x}_{6}\right)$, land area $\left(\mathrm{x}_{7}\right)$, and dummy risk lover attitude $\left(\mathrm{d}_{1}\right)$, and factors that influence not significantly are production $\left(\mathrm{x}_{1}\right)$, fertilizer costs $\left(\mathrm{x}_{4}\right)$, drug costs $\left(\mathrm{x}_{5}\right)$, experience $\left(\mathrm{x}_{6}\right)$, and dummy of risk averse attitude.

\section{REFERENCES}

Fauziah, Elys et al. 2010. The Influence of Risk Preference of Farmer Production in Tobacco Productivity: Stocastical Frontier Production Function by Means of Heteroskedastic Error Structure. Journal of Forum of Post Graduated 33(2): 113-122.

Hasan, M. 2012. The Core of Material Statistic 1 (Infference Statistic). Jakarta: PT Bumi Aksara.

Inayatin, Nur. 2011. Farm Management Analysis of Besuki Na-Oogst Tobacco in Jember Regency. Thesis. Social Economic Department, Agricultural Faculty,University of Jember.

Khanisa, Fatma Artanti dan Sudrajat. 2012. The Income Analysis of Tobacco Farmer in Menggoro Village, Tembarak Sub District, Temanggung Regency. Journal of Bumi Indonesia Vol 1 (3): 382-390.

Masruroh, Ariyani. The Tobacco Farming Contribution To Household Incomes In Salamrejo Selopampang Temanggung Central. Thesis. University of Yogyakarta.

Soetriono. 2017. Competitiveness of the agricultural analysis. Malang: Bayumedia.

Suratiyah, Ken. 2015. The Science of Farm Management. Jakarta: Penebar Swadaya.

Wardani, Nia Susilo. 2015. Farmer's Attitude Towards Tobacco Farm Management Risk in Klaten Regency. Journal Enterpreneur and Enterpreneurship Vol. 4(1\&2): 25-32. 